\title{
LEPCHA NARRATIVES OF THEIR THREATENED SACRED LANDSCAPES
}

\author{
Transforming Cultures eJ ournal, \\ Vol. 3 No 1, February 2008 \\ http:// epress.lib.uts.edu.au/journals/TfC
}

\section{Kerry Little ${ }^{1}$}

Dorjee Tshering Lepcha rises with the sun each morning. He walks out of his living room into the crisp early air and enters a small prayer room. The room is sparsely decorated, an altar on one side and a cushion and small stool on the other. The altar is modestly adorned with leaves, flowers and fruit. Dorjee sits cross-legged on the floor, the cushion softening the impact of the cold concrete, and places the manuscript for a Lepcha prayer on a small stool in front of him. To his side, he rests a bamboo flute. First he chants; the morning chant to Mother Nature, informing her that he will surely intrude on her that day and asking her forgiveness in advance. Then he lifts the flute to his mouth and gently blows a welcome to the new day, its melancholy sound sending an apology simple and pure; its sincerity clear. In his village, Manegumboo, at $12^{\text {th }}$ Mile in Kalimpong, the same ritual is taking place in seven of the 30 households. For these are animist homes, where the Children of Mother Nature live. ${ }^{2}$

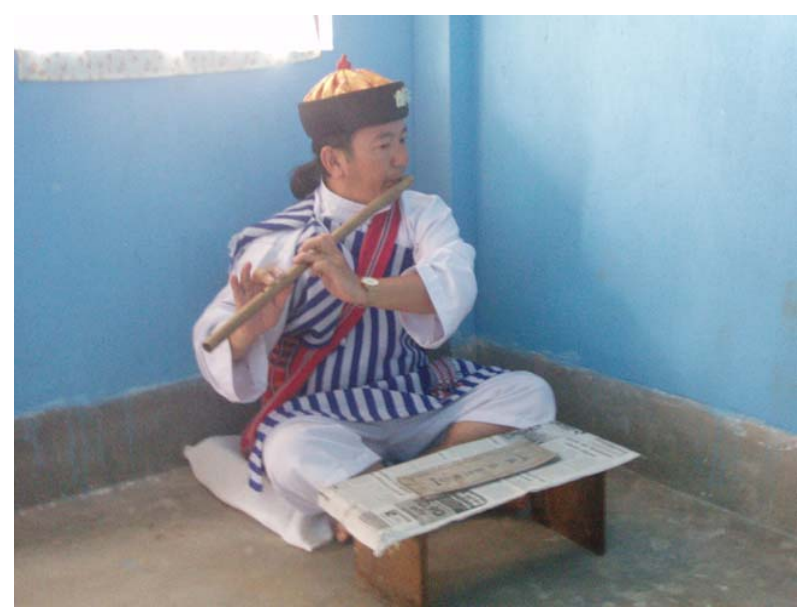

Photo 1: Dorjee's morning prayer to Mother Nature

\footnotetext{
${ }^{1}$ Kerry Little is a PhD candidate at the University of Technology Sydney.

${ }^{2}$ Dorjee's village with its 25 percent animist homes is rare, for nature-worshipping Lepchas in the Darjeeling district make up just five percent ${ }^{2}$ of the Lepcha population. The remainder is either Buddhist or Christian. For these Lepchas to hold on to their cultural source has proved challenging, and their small numbers show how few have managed to do so.
} 
I meet Dorjee on a visit to the East Indian Himalaya, where I have come to record the folk stories of the Lepchas, the majority who live in Kalimpong, Darjeeling and Sikkim. Working with the Lepchas, learning their traditional and contemporary stories, I hope to learn how social change has impacted on Lepcha society and whether the passing of old stories to new generations, helps them connect with their indigenous culture. I was first approached to write the stories by a Lepcha man living in Sydney. A Christian from Kalimpong in West Bengal, he did not speak his mother tongue. However as he passed through middle-age he contemplated the stories his mother and older relatives had told him in his youth and was concerned that the stories would die when the elders passed away as his family had not documented these narratives. As a writer I was interested in exploring new narratives and as a frequent visitor to the Himalayan region and recent visitor to the Indian north-east, I was intrigued that I had not previously heard or read anything of the Lepcha tribe who are the indigenous people of that region. ${ }^{3}$

In order to meet the Lepchas who live closest to a traditional life, one must travel to the Dzongu, the Lepcha Reservation in remote North Sikkim, where they currently live a quiet life as cardamom farmers. However the cardamom harvest has diminished in the past four to five years and change is coming to the Dzongu, forced in part by the change in economic circumstances brought by the loss of the cardamom cash crop, ${ }^{4}$ but also by the advanced schooling of the current generation of Lepchas, who describe themselves as 'the first educated generation' and have different aspirations than their parents. This younger generation face a choice: a future outside Dzongu working in Sikkim in government jobs or self-created businesses, or return to Dzongu after their schooling ${ }^{5}$ and create a new economic future there by working the land differently to their parents.

\footnotetext{
3 The Lepchas are legally recognized as Indigenous in India through the Government's listing of their people as a 'Scheduled Tribe.' They were recently recognised as having 'primitive tribe' status.

${ }^{4}$ Dawa Lepcha, who owns a farm in Lingdong in Dzongu advised that no one knows why the cardamom crop is diminishing including the Sikkim Department of Agriculture which has been investigating the issue.

${ }^{5}$ Most of the young Lepchas I met living in Gangtok who described themselves as the 'first educated generation' were awarded scholarships to the Tashi Namgyal Academy (TNA) which is considered the best school in Sikkim. Many then undertook further studies at North Bengal University in Siliguri, or at universities or colleges in major Indian cities such as Kolkata or Delhi. Lepchas who study at TNA leave the Dzongu and live in hostels, visiting home during festivals and holidays.
} 
Lepchas everywhere consider the Dzongu to be their holy land and that their race was created in Dzongu by Mother Nature and that Mount Kanchenjunga is their mother mountain. ${ }^{6}$ The Lepchas belief that the Dzongu is sacred is not wholly related to religion for Lepchas are Buddhist, Christian and to a lesser extent Hindu. The belief predates the colonialisation of the Lepchas and relates to their traditional culture which they describe as nature-worship and which they practiced before taking up the religion of others.

The Lepchas in the Dzongu (and elsewhere in Sikkim) are mainly Buddhist; however their traditional nature worship rituals and beliefs sit comfortably alongside the Buddhist doctrine they have followed since the Bhutias arrived from Tibet with Buddhism in the $13^{\text {th }}$ century. They consider that nature's gifts give them life in the form of food, medicine and prayer and many of their festivals and prayers pay homage to nature.

I have travelled to North-east India - to Lepcha Land - several times to record Lepcha narratives. My methodology is to seek out meetings with elders and ask if I can record old stories. I am accompanied by young English speaking Lepchas who interpret for me. The interpreters, who are nearly always related to the story-tellers, are often hearing the old stories for the first time.

My references, when I started recording the stories, were studies done by European anthropologists and explorers in the earlier part of the last century (Gorer: 1938, Morris: 1938, Siiger: 1967) who included Lepcha folk stories in their work, plus the memoirs of British Colonial commentators (Hooker: 1854, Mainwaring: 1876, White: 1909). In the process of seeking out the old stories I am now hearing, through the young Lepcha interpreters, a contemporary story has emerged of an imminent threat to the Lepchas' landscape that will be devastating to their language and culture: the construction of six mega-hydro electric projects in the Dzongu Lepcha Reserve in North Sikkim.

6، The first and the foremost primogenitors of the Lepchas, Fodongthing and Nazaongnyo were created by God from the pure, virgin snows of Kingtsoomzaongboo Choo's pinnacles and sent them down to live, prosper and spread all over the fairy land of Mayel Lyang that lies on the lap of Kingtsoomzaongboo Choo that is Mount Kanchenjunga.” Tamsang, K P - 1983 relayed by Dr DC Roy, Kalimpong College Darjeeling in King Gaeboo Achyok 2005, a Lepcha Bilingual Magazine, pub Indigenous Lepcha Tribal Association. p.2 
Like many westerners I am attracted to what we might consider the exotic world of small, indigenous and remote communities however with each visit to 'Lepcha Land' it is not the exotic that brings me back, rather it is the knowledge I learn from being with a group of people which is undergoing change brought by economic imperative, education and globalisation; and the strength I gain from the relationships formed with those who are courageously navigating - and at this time opposing - change to their culture and identity.

It is this contemporary story that I examine in this paper, the story of how modernity and in particular, large-scale development in the form of mega-hydro electric projects threatens Lepcha culture and how the young Lepchas who when faced with the loss of their culture, are attracted back to the traditions of their elders. The paper is drawn mostly from the Lepchas' narrative of what they describe as 'a violation of a sacred landscape ${ }^{7}$ and starts with a 2006 meeting held in Gangtok that was a turning point for the Lepchas' battle for their land, their culture and their narratives.

On the 12th December, 2006 I join a small number of Lepchas who gather in BhutiaLepcha House (BL House), a run down building on Tibet Road in Gangtok. They are there to discuss the impact of soon to be built hydro-electric (hydel) power projects on their lives. The State Government of Sikkim has commenced construction on some of 26 proposed hydels in the small, mountainous state. The most contentious hydel, Teesta Stage IV, is slated to be built in the Dzongu Lepcha Reserve. It consists of six projects (plus one other on the border of Dzongu at Dikchu which is near to completion). The Lepchas are protesting the dams on many grounds: that as nature-worshippers their land is sacred and should not be destroyed by development; that the Dzongu is recognized as a reserve ${ }^{8}$, and since only Lepchas who are from there are allowed to enter the reserve it should not be the site for the hydro projects. They also argue that the projects will bring thousands of workers from outside Sikkim into the Dzongu for several years while work is completed and they will outnumber the population of 7,000 Lepchas; and, since the workers have different customs and beliefs, their dominant presence will soon dilute

\footnotetext{
${ }^{7}$ Letter from Affected Citizens of Teesta (nd) which is sent to NGOs and interested parties p.4

${ }^{8}$ The Dzongu was declared a Lepcha reserve in 1957 by the last Chogyal of Sikkim in recognition that it is the Lepcha's sacred land and should be preserved for Lepchas.
} 
and destroy Lepcha culture. The protest is also on environmental grounds, the Lepchas claiming that the delicate ecology of the Dzongu, which is on the border of Mount Kanchenjunga national park and part of the Himalaya biodiversity hotspot, ${ }^{9}$ and like the rest of Sikkim prone to landslides and earthquakes, will not survive the development.

The meeting at BL House is a compromise, for it had started life as a rally which would stretch from Baluakhani above Gangtok to Assembly House: the State Government's offices. The days just prior to the $12^{\text {th }}$ have been divisive for many in the community with one Lepcha association deciding not to support the organisers, Affected Citizens of Teesta (ACT), and calling for dialogue with the Government, rather than the more confronting march. The Sikkimese people are not prone to acts of defiance or aggression; many who work in government positions fear retribution for action that may be perceived as disloyal. ${ }^{10}$ The differing approaches by the Lepcha Associations is reported daily in the Gangtok English Language newspaper, Sikkim Express ${ }^{11}$, which first writes that the ACT does not have support of the All India Lepcha Student Development Organisation and other associations. ${ }^{12}$ The Concerned Lepchas of Sikkim (CLOS) immediately publicises its support for the ACT by saying "it is beyond anybody's doubt that the Hydel Power Projects in Dzongu will bring in its wake innumerable ill-effects to Dzongu and other area, which will certainly have adverse affect on the lives of the Lepchas of these areas...it is pertinent to mention that the Proclamations and Old Laws enacted during the reign of Chogyal prohibited settling and/or carrying on any occupations in Dzongu by the outsiders." (NE News Bureau 2006, p.1 $)^{13}$ So with the Lepcha community divided over how the objection to the hydels should be made, a compromise of sorts is reached the morning of the $12^{\text {th }}$ with the rally being downgraded to a public meeting on the understanding that if the Chief Minister of Sikkim, Shri Pawan Chamling, does not meet the activists and agree to

\footnotetext{
${ }^{9}<$ http://www.biodiversityhotspots.org/xp/Hotspots/himalaya/Pages/default.aspx > $\quad$ Accessed 27 September 07

${ }^{10}$ I heard from several Sikkimese that many who worked in government positions are reluctant to take a position on issues that differs to the government's official position and feel compromised when asked to.

${ }^{11}$ AILSDO not to participate in ACT's December 12 rally, Sikkim Express, 11 December, 2006, p.1

12 The Sikkim Lepcha Association, Sikkim Lepcha Youth Association, Lepcha Writers’ Forum, Sikkim, Lepcha Literary Organisation.

13 NE News Bureau (2006) Concerned Lepchas of Sikkim backs ACT, Sikkim Express, 12 December 2006, p1 accessed April 2007.
} 
review the projects then the Lepchas will hold an all night candlelight vigil at the Statue of Unity ${ }^{14}$ in the middle of Gangtok.

The Sikkimese Government hopes to yield approximately 5,000 MW of power valued at approximately Rs. 2,000 crore per annum ${ }^{15}$ by tapping into 'the enormous hydroelectric potential from the run of the two snow-fed perennial rivers Teesta and Rangit'. It exhorts the 'pollution free nature of hydel power, the low variable costs of generation, and the growing demand-supply gap for electricity in the country' when persuading the Sikkimese of the benefits of developing hydro-electric power. Its vision is of a 'prosperous Sikkim with an effective public sector, thriving trade, abundant hydroelectric power, tourism, horticulture and floriculture and without poverty, illiteracy and unemployment. ${ }^{, 16}$

The 26 dams proposed for Sikkim are part of the central Indian government's program of dam construction to create another 200 billion cubic metres of storage through the 50,000 MW Hydroelectric Initiative, launched in May 2003. ${ }^{17}$

"If utilised with wisdom, these rivers and streams could be converted into a white gold,” said the Chief Minister in his 2001 New Year's Day speech. He closed with this undertaking: 'We have taken special care to ensure that development projects do not produce an adverse effect on our fragile ecosystem. We have also been cautious to see that Sikkimese tradition and culture is preserved for our posterity. In short we want to project our indigenous culture and tradition in the garb of modernity. ${ }^{, 18}$

\footnotetext{
14 The statue of unity commemorates the treaty between the Lepcha and Bhutia leaders and the creation of the Kingdom of Sikkim.

${ }^{15}$ Dzongu projects to stay: CM, The Telegraph online, 23 July 2007 (accessed $24^{\text {th }}$ July).

16 <http://www.sikkimipr.org/GENERAL/ECONOMY/ECONOMY.HTM> (accessed March 2007) More recent news reports (Jan 08) state the yield is 8,000 MW.

17 See Shripad Dharmadhikary, (2007) Have river, will dam, HIMAL SOUTHASIAN, September 2007 (accessed 10/09/07).

18 Politics, Programmes and Vision for the new Century, speech delivered on 1st January 2001 in Gangtok by Chief Minister Pawan Chamling, found on <http://www.sikkimipr.org/CMO/speeches/SPEECH_1.HTM>
} 
Six years after the Chief Minister made this commitment, the group of around 30 Lepchas, dressed in the garb of tradition wait quietly in the large dusty room at BL House for the meeting's conveners to arrive. It is after the proposed start time of noon and seating is arranged for ten times the number of people who are there. Banners hang defiantly from the walls 'Save North Sikkim, Protect Kanchejunga National Park, Save Our Environment. 'Save Sikkim, Save Article 371(f) ${ }^{19}$, Stop mega Hydro Electric Project' but despite the strong message, the empty room appears to signal a lack of support for the activists. I was invited to the meeting by a committee member of ACT who I had met while organising a visit to Dzongu to record folk stories. He had not known any of the stories but had arranged for me to visit his village with his sister to meet elders. While I was there I had heard that some Dzongu landowners had been promised money in return for their land and for supporting the development of the power projects and as such, were not supporting ACT in the numbers they need to have a strong community voice. I worry that this small group might be it; that the audience may outnumber the organisers, and that I will be witness to a downturn in the social movement that needs so much support. For some time little happens, a few people dribble upstairs but don’t bother to take a seat as there are hundreds of chairs available and little else happening.

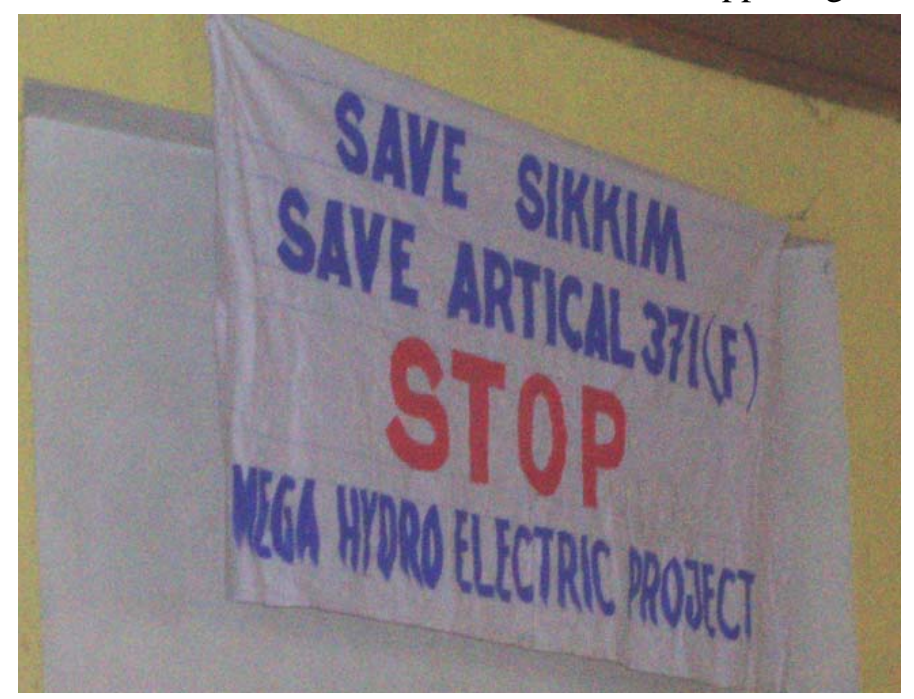

Photo 2: ACT meeting banner

Someone leaning against the window calls out and we rush over. The mood instantly changes and a soft breeze of confidence replaces the down-at-heart air that preceded it.

\footnotetext{
${ }^{19}$ Article 371F of the Indian Constitution allows for special provisions with respect to the State of Sikkim including that the privileges of the Lepcha-Bhutia groups are assured as minorities, that their rights and interest will be protected and that the Government of Sikkim make provision for the number of seats in the Legislative Assembly of the State of Sikkim for them and that the Government of Sikkim shall have special responsibility for peace and for an equitable arrangement for ensuring the social and economic advancement of different sections of the population of Sikkim and in the discharge of his special responsibility under this clause, the Governor of Sikkim shall, subject to such directions as the President may, from time to time, deem fit to issue, act in his discretion. $<$ http://www.answers.com/topic/constitution-of-india-part-xxi>
} 
Looking down to the street below I can see why: a convoy of around 30 jeeps slowly makes its way up Tibet Road; each carrying around a dozen people, all who have made the long and expensive trip from the Dzongu to hear the activists' perspective on what is happening to their land and to make their voices heard. Old men wearing Thokro-Dum, the traditional Lepcha tunic, and young men in jeans and sneakers make their way past the police who casually hang around outside. Upstairs, Lepcha lamas group together like a voting block of maroon sitting in a field of colour, for the grandmothers, mothers, daughters and sisters are there wearing their Dumvum, which flows from their shoulders to the floor in every shade of their rich and varied land. The atmosphere is festive and for the next couple of hours, hopeful optimism is the unifying thread that links the drama, humour, warnings, ideas, combativeness and solutions offered to the audience by the committee members of the Affected Citizens of Teesta. The President of the ACT, former forestry and environment minister for Sikkim, Athup Lepcha talks quietly and everyone listens respectfully; his son shouts defiantly and the audience responds with claps and cheers. Other than occasional fragments of conversation being translated for me by the students standing nearby, I don't understand a word that is said that day, but I feel I know what is happening. It is apparent that many people are hearing things for the first time and they are concerned by what they hear and unified in their desire to stop the development on their land. There is hope, strength, respect and a touch of militancy in the cheers of 'auchuley, ${ }^{20}$ that pepper the audience's response to each speaker. They are known for their shy, quiet persona but that day 500 or more Lepchas, from the remote North of Sikkim, where they may encounter just a handful or less people each day, discover their loud voices and they holler and clap and laugh and yell their support for the group who will lead them in this fight for their sacred land and culture.

When the meeting breaks for lunch the ACT committee members make their way to the office of the Chief Minister. They are determined to get the outcome they want and they return an hour and a half later with the news that the Chief Minister has met them and agreed to review the Dzongu hydel projects. According to newspaper reports the following day, the Chief Minister offered to review 'every aspect' of North Sikkim hydel projects and also expressed 'deep concern' for the people of North Sikkim...that

${ }^{20}$ Auchuley is a Lepcha word which is used to show approval, agreement, pride, celebration and on the $12^{\text {th }}$ December; all of those things and unity. 
culture, tradition and identity would never be compromised for the sake of economic development alone. ${ }^{21}$ I am told by the activists that the $12^{\text {th }}$ of December is the day the movement gains momentum; a turning point in the campaign to stop the Dzongu hydel projects. However twelve months later, the government review has not happened and the boys in jeans, together with their Lepcha sisters, who are the first educated generation of Dzongu Lepchas, are using their knowledge and experience to fight for their land and are reconnecting with Lepcha narratives about their land in order to embrace their unique identity; but also to communicate through traditional stories, their claim that Dzongu is a holy land to Lepchas.

The North District of Sikkim, where the Dzongu is located, is the largest among the four districts of Sikkim, is the least populated and has an environment that is currently least disturbed by external agencies. The district covers nearly 60 percent of the total land area of the state but houses less than 8 percent of the state's population. The density of population in the district is only 10 persons per sq $\mathrm{km}$. The dominant ethnic groups living in the district are the Lepchas and the Bhutias. The remoteness and the hostile landscape $^{22}$ of North district not only checked indiscriminate inflow of population, but also helped preserve the traditional mode of life of the indigenous ethnic groups. ${ }^{23}$

The town of Mangan, the self-described 'Large Cardamom Capital of the World', is the district headquarters of North Sikkim. At an altitude of $3950 \mathrm{ft}$, it is the gateway to the most popular tourist destinations of Sikkim, including the Yumthang Valley and the sacred Gurudongmar Lake.

21 Rai, Remuna, CM offers to review 'every aspect' of North Sikkim, NOW! Daily, 13 December, 2006. p.1

22 I assume Choudhury's description of the landscape as hostile applies to its inaccessibility and difficult to traverse terrain, rather than any relationship to the people of the Dzongu who are peace-loving and welcoming. 
Mangan is the kind of town a traveller stops in on the way to somewhere else to stock up on supplies at the Mangan bazaar or catch a taxi to the district collectorate to obtain a permit to visit the Dzongu Reserve. From Mangan, you can see where you are headed, to the high lakes and mountains above, or the famous Phodong Monastery or Kabi Longstock sacred grove below. Apart from the occasional music festival, not a lot happens in Mangan but a year before the meeting at Bhutia- Lepcha House, in December 2005, there was a large gathering of concerned citizens who descended on the town for a one day Satyagraha ${ }^{24}$ to protest against the proposed mega hydel power projects. Two hundred people from the Dzongu Lepcha Reserve, with members of the Affected Citizens of Teesta (ACT) made the somewhat arduous journey, from villages inaccessible by road to join the protest. ${ }^{25}$ Activism is not a role that sits naturally with the Lepchas, who often describe themselves as shy nature-lovers, however the prospect of losing their land and culture has energised many to take it up. In September 2006 ACT members and their supporters were detained by police when they blocked the road at Sankalang Bridge, which connects the Lepcha Reserve of Dzongu with Mangan in North Sikkim, to stop a team from the Hydel development company from entering the reservation. ${ }^{26}$ The activists were questioned and let go, but the protest signaled a change in the profile of the ACT and a growing momentum for their cause.

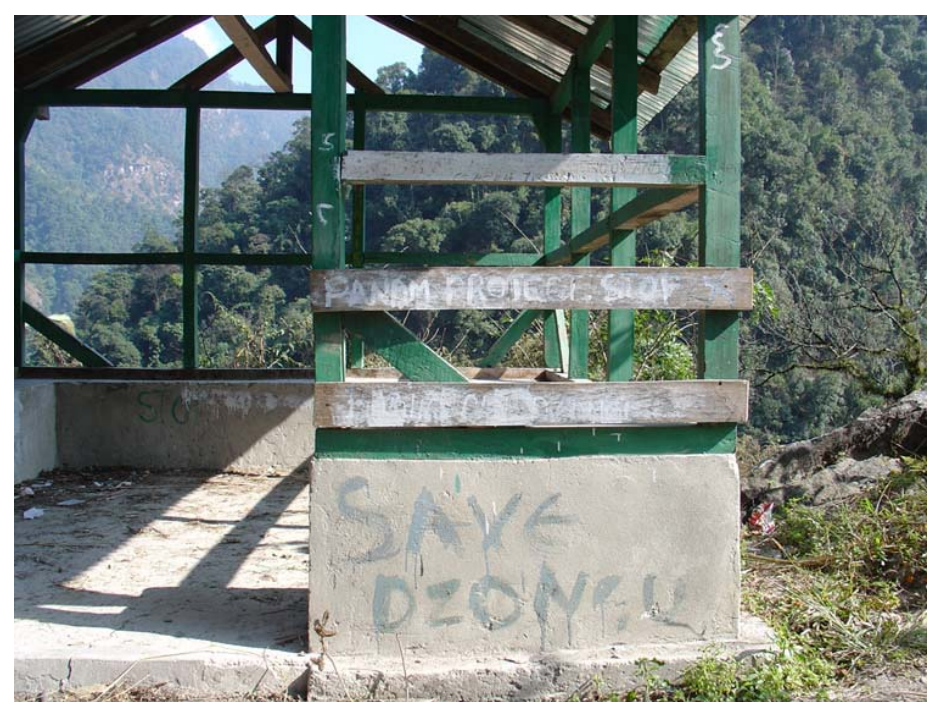

Photo 3: Graffiti protesting the hydels in Dzongu

\footnotetext{
${ }^{24}$ Satyagraha - the form of nonviolent resistance initiated in India by Mahatma Gandhi in order to oppose British rule and to hasten political reforms.

25 This information was provided by Sherap Lepcha, a member of Affected Citizens of Teesta on email dated 13/11/06

${ }^{26}$ Sarikah Atreya. (2006), ACT supporters detained for questioning, Midweek, 6-12 Sept, 2006, p.5
} 
Affected Citizens of Teesta (ACT) was formed in 2003 and has held awareness meetings and protests since to stop the irreversible damage that will be done to the biodiversity, environment, and demography of North Sikkim. The ACT is at pains to point out that they are not anti-development but anti mega development. "We welcome the micro-hydro power project instead of this mega-hydro power project as it has less affect on the environment," says committee member, Sherap Lepcha. "Our idea is - whatever comes - local people should be given first preference and local people should get benefits. The micro-hydro power project is very small so the local people will get employment, [there will be] less destruction and less environmental impact...we have no problem with that. But this mega- hydro power project has a lot of impact on the environment."27

The government argues that the large projects are justified as they will bring power for India and economic benefits to Sikkim, including employment for Sikkimese however the activists argue that the cost is too high. “...The projects involve diverting up to 8590 percent of the river flow in the lean season through long tunnels before the water is dropped downstream. Not only will this destroy the riverine ecology but a cascade of projects will mean the Teesta is in full flow only in brief stretches between the two hydel projects,” says Pemzang Tenzing, a civil engineer and ACT member. ${ }^{28}$

There are other issues with the proposed dam sites. The Carrying Capacity Study of the Teesta Basin in Sikkim, commissioned by the Ministry of Environment \& Forests, Government of India urged caution in relation to the Teesta projects on environmental, safety and cultural grounds. ${ }^{29}$

\footnotetext{
27 These comments were made by Sherap Lepcha at Tingvong Village, Dzongu on 7 January 06 in conversation with Susannah Gupta, freelance journalist from Berlin and Kerry Little.

${ }^{28}$ Neeraj Vagholikar, (2007) Satyagraha for the Teesta, Tehelka.com, 20 September 2007, <http://www.tehelka.com/story_main34.asp?filename=cr290907SATYAGRAHA.asp> (accessed 20/09/07)

${ }^{29}$ Maitreyee Choudhury, (nd) Carrying Capacity Study of Teesta Basin in Sikkim Volume-X, Sociocultural, Environment, Commissioned by Ministry of environment and Forests, Government of India, Sponsored by National Hydroelectric Power Corporation Ltd., Fairdabad, Executive Summary, p. 29. (the report is undated however the references date as late as 2002)
} 
The Dzongu is known by Lepchas as Mayel Lyang, which means land of hidden paradise. It is where the largest tree is never cut down, the strongest deer is never hunted $^{30}$ and wild orchids sprout aimlessly from the top of trees, making pink and purple bursts in the sky.

The Lepchas were once alone in Mayel Lyang for so long many people say they were there from the beginning of time. But then, about six or seven hundred years ago, strangers arrived.

First, the Tibetans came and brought Buddhism and sovereignty. Then the English arrived with commerce and Christianity.

Then, the Nepalese flowed across the border to work in the tea-gardens built by the English and the Indians moved up to the mountains to escape the hot, dry plains.

Men from Britain and Europe started climbing the peaks, stepping on their mountain deity, Kanchenjunga, leaving the imprint of their climbing shoes and their conquest over her surface.

And one day, the Lepchas came out of the forest and realised they were the smallest tribe in the land.

In Mayel Lyang, the nature-worshipping Lepchas include every leaf, blade of grass, all creatures, and the water from the heavens, rivers and lakes in their prayers. Each clan has its own 'Chu', a Himalayan Peak, and 'Da', a lake and offer their prayers and supplications to their respective 'Chu'. ${ }^{31}$ Long before people from other nations trod the land that rests at the foothills of the East Indian Himalaya, Lepchas lived there peacefully, their habitat protected from strangers who found the peaks that wove their way along the ridges of Mayel Lyang an impassable cloak of protection.

\footnotetext{
${ }^{30}$ I heard this on a few occasions from Lepchas when they described ancient Mayel Lyang (Dzongu). There is also a reference in the report entitled Documentation of the traditional ecological knowledge, capacity building needs of traditional institutions for sustainable utilisation of natural resources in Sikkim and Darjeeling Hills, Eastern Himalayas, WWF for India, Final Report, 2004, p. 27 which states 'Lepcha is a nature worshipping community also known as Lingee. Big trees across the species are traditionally not allowed to be cut down.'

${ }^{31}$ A Staff Reporter, (2005) Chu Rum Faat, prayers and offerings to the Himalayas, King Gaeboo Achyok 2005, a Lepcha Bilingual Magazine, Indigenous Lepcha Tribal Association, p.10.
} 
Sikkimese Lepchas ${ }^{32}$ observe major festivals on the Buddhist calendar associated with the life and teachings of the Buddha plus festivals unique to Sikkim. These include Phang Lhabsol: the worship of Kanchenjunga's unifying powers and the signing of the treaty of blood brotherhood between the Lepchas and Bhutias and other festivals that commemorate Guru Rinpoche, who brought Buddhism to Sikkim. Places where Guru Rinpoche visited are considered most sacred by Sikkimese Buddhists.

Lepchas everywhere consider the Dzongu - Mayel Lyang - their holy land and the birthplace of the first Lepchas. They observe their traditional nature-worshipping festivals such as the festival of Tendong Lho-Rum-Faat: whereby Lepchas pay obeisance to the Tendong Hill which saved their tribe from annihilation in the great flood, and Chu Rum Faat, an offering to the Himalayas. Narratives relating to the rivers of Sikkim flow through Lepcha folklore and a story about the uniting of the rivers Teesta and Rangit, features prominently in Lepcha marriage ceremonies. In following their indigenous traditions, the Lepchas worship of all nature and their adopted religion, Buddhism, adds a layer of specificity relating to Buddhist sacred places. To the Lepchas, environment and religion are intertwined.

The Lepchas believe their souls go to Dzongu when they die. Lyangsong Tamsang, a Lepcha leader from Kalimpong, which is situated outside the Dzongu Reservation, together with thousands of Lepchas from West Bengal, is protesting the dams. He narrates the path of his clan's (Tamsangmoo) soul after death to explain the importance - and sacredness - of Dzongu to Lepchas everywhere. "The soul will go to the confluence of Teesta and Rangyong rivers, the river below Passingdang. The Mun ${ }^{33}$ (Priestess) will take the soul through Teesta River and when it arrives at the confluence of Teesta and Rangyong it will follow Rangyong, the holiest river of the Lepchas which flows in the middle of Dzongu. The Mun takes the soul through the back of the river Rangyong and tells the soul you are dead and you must recognise it for the soul will always say I am not dead, I am still alive. The Mun will then say 'you are dead, step on the sand of Rangyong River and tell me if you see your step.' The answer is no,

${ }^{32}$ Lepchas in the Darjeeling district (including Kalimpong) also observe the same Lepcha festivals as those in Sikkim. There is also a large Lepcha population in the Darjeeling district who follow Christianity.

${ }^{33}$ The Mun is a powerful Lepcha Priestess, also known as a shaman, who conducts many rituals, including a ritual to ensure the soul of a deceased person has a clear path back to the Dzongu where the Lepcha race was created. 
(because you are dead) so she takes the soul to where it rests. Our Mun speaks of this river, speaks of the mountain and speaks of the trees; everything the Mun describes, we know it is Dzongu." ${ }^{34}$

If the projects proceed, water from the Rangyong River will be diverted into underwater tunnels as part of the 280MW Panam Project.

It would be incorrect to say all residents oppose all the Hydel projects. It is Stage IV that was singled out in the Carrying Capacity Study of Teesta Basin as being more objectionable to the locals than Stages III and VI. 'The local people in almost all the proposed project sites are aware of the benefits as well as the problems associated with the project. During fieldworks in villages close to the site of Stage III near Chungthan, it was observed that the local communities Lepchas in particular, fear influx of outsiders. The Lepchas who have long been reduced to a minority in their land fear that the influx of project workers from outside the state will push them further and make them marginalised in their homeland. A section of the community opines that the project will be problematic for them as it touches the Lepcha reserve of Dzongu in North Sikkim... local people are somewhat skeptical about the proposed project...however the people are to some extent ready to accept the proposed project provided certain conditions are met. $^{, 35}$

The recommendations for Stage IV (inside the Dzongu) however, were quite different. Choudhury noted that 'The people of the Dzongu, irrespective of their social or occupational status, unanimously and vehemently oppose Teesta Stage-IV. Under such circumstances it is recommended that the sentiments of the indigenous tribes be reckoned with before reaching any decision. ${ }^{, 36}$

\footnotetext{
${ }^{34}$ Interview with Lyangsong Tamsang in Kalimpong, 28 January 2008.

35 Maitreyee Choudhury, (nd) Carrying Capacity Study of Teesta Basin in Sikkim Volume-X, Sociocultural, Environment, . Chapter 5, p. 133-4. Report commissioned by the National Hydro Electric Power Corporation. (Report is undated but references date as late as 2002)

${ }^{36}$ Maitreyee Choudhury, (nd) Carrying Capacity Study of Teesta Basin in Sikkim Volume-X, Sociocultural, Environment, . Chapter 5, p.137. Report commissioned by the National Hydro Electric Power Corporation. (Report is undated but references date as late as 2002)
} 
Unlike tribals elsewhere whose land has been appropriated for hydro development, the Lepchas are not facing mass displacement as the Dzongu is sparsely populated, the land required for the hydels is not the entire Dzongu and the land acquisition is voluntary. Opponents of the development claim that landowners have been tricked into selling their land. "They made us sign documents which we did not know were for selling our lands,” said Passang Lepcha, a landowner from Sakyong. ${ }^{37}$ However other landowners say they sold their land willingly. At a meeting of 300 Dzongu residents at Namprikdang in the Dzongu (8 Jul 07), landowners 'stressed that none of them had been forced into parting with their lands and added that even they were concerned about the environment and culture and had ensured adequate safeguards to protect them. ${ }^{38}$

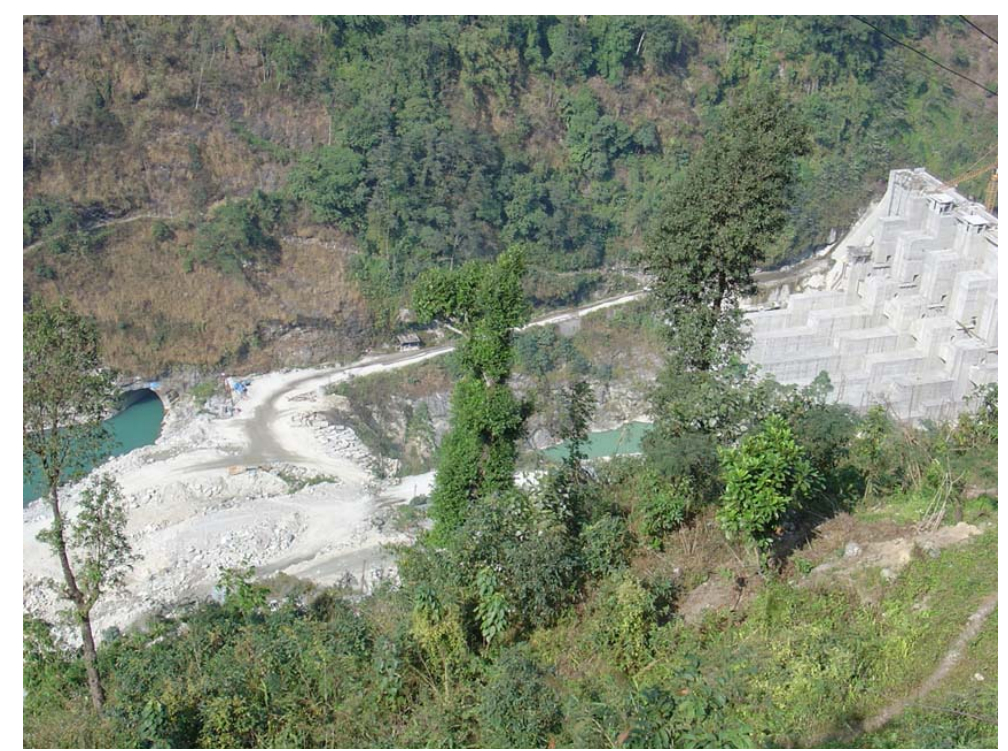

Photo 4: Hydel on Dzongu border at Dikchu

In April 2006 thousands of pilgrims attended an important festival at Tholung Monastery. The festival, which occurs every three years, involves the opening of thirteen sacred boxes which house 'the treasures' of monasteries that were brought from West Sikkim to Tholung during the Nepalese invasion in the $17^{\text {th }}$ century. The walk from the road to Tholung is a vertical and arduous 15 kilometre trek, for Tholung is at an altitude of 8,500 feet. To the Lepcha and Bhutia tribes determined to see the treasures though, the rain and difficult terrain is not a deterrent. There is a folk story

37 Mita Zulca, (2007) Protest in the Hills, Talk Himalaya, Vol 1. No 1. July-Aug 2007, pub: Little Kingdom, p.14.

${ }^{38}$ Deepak Sharma (2007) Dzongu residents and landowners endorse hydel options, NOW! 9 July 2007, p.1 
about Tholung that relates to a curse on the royal family of Sikkim and because of this curse, no member or descendent of the Sikkimese royal family visit Tholung.

There is a sacred cave above Tholung Gompa where the Guru Rinpoche is believed to have spent many days. The impression of volumes of Holy Scriptures on the nearby rocks which Guru could not take to Tibet is not only an awe-inspiring sight but strongest evidence of Guru's stay in this land made holy by his presence. ${ }^{39}$

When researcher Vibha Arora approached the boundary of the Tholong sacred grove, her friend and guide, Chumsay Nangpa instructed her to assure the Tholung protective spirits about her honest and good intentions to undertake research on this land and seek their blessings, 'reiterate the purity of your thoughts, your intentions, and your actions.' Arora was instructed to pluck some leaves, offer a silk scarf, place sweets and money upon a shrine that is considered the residence of the protective spirits of Tholung. In her examination of sacred landscapes of the Lepchas in Sikkim, Arora relates:

'...not a single leaf or a pebble can be taken away from this sacred area. Pilgrims are instructed to even dust their clothes and shoes for any loose leaves and twigs, as otherwise the Tholung spirits would get angry and make them sick...only holy water and offerings returned by the lamas can be taken back as divine blessings.. ${ }^{40}$

Arora observed that the sacred landscape of Tholung constitutes the nerve centre of Lepcha social life and epitomises Sikkimese Buddhism of nationalist practice. It comprises an uninhabited human tract of mountainous forests adjacent to the wish fulfilling pilgrimage site of the Tholung temple that preserves the sacred treasures of the former Buddhist Kingdom of Sikkim. The landscape comprises a dzgon-pa (a Buddhist temple), a sacred grove, a sacred hot spring, and some sacred caves that are used by monks to meditate in seclusion. ${ }^{41}$

\footnotetext{
$39<$ http://www.samdruptse.org/gurupadmashamva.htm>

${ }^{40}$ Dr Vibhya Arora, (2006) The Forest of Symbols Embodied in the Tholung Sacred Landscape of North Sikkim, India, p. 65

${ }^{41}$ Dr Vibha Arora, (2006) The Forest of Symbols Embodied in the Tholung Sacred Landscape of North Sikkim, India, Conservation and Society, Vo 14, No1, Mar 06, p. 55-83
} 
The Tholung Gompa is located about 20 kilometres from the Lingzia village where a dam site is proposed. A concrete gravity dam will come up on the confluence of the Tholung Chu and Rangyong Chu, while the power house will come up near Panam village, connected by a $9.8 \mathrm{~km}$ head race tunnel along the right bank of the river. ${ }^{42}$ Any mega project in the vicinity of this area is definitely a cause for concern as it would involve large influx of migrant workers from outside the State. The increased human activity in the area can be a security threat to the Monastery and its sanctity. This is a concern shared by many intellectuals and followers of Buddhism in the State. ${ }^{43}$

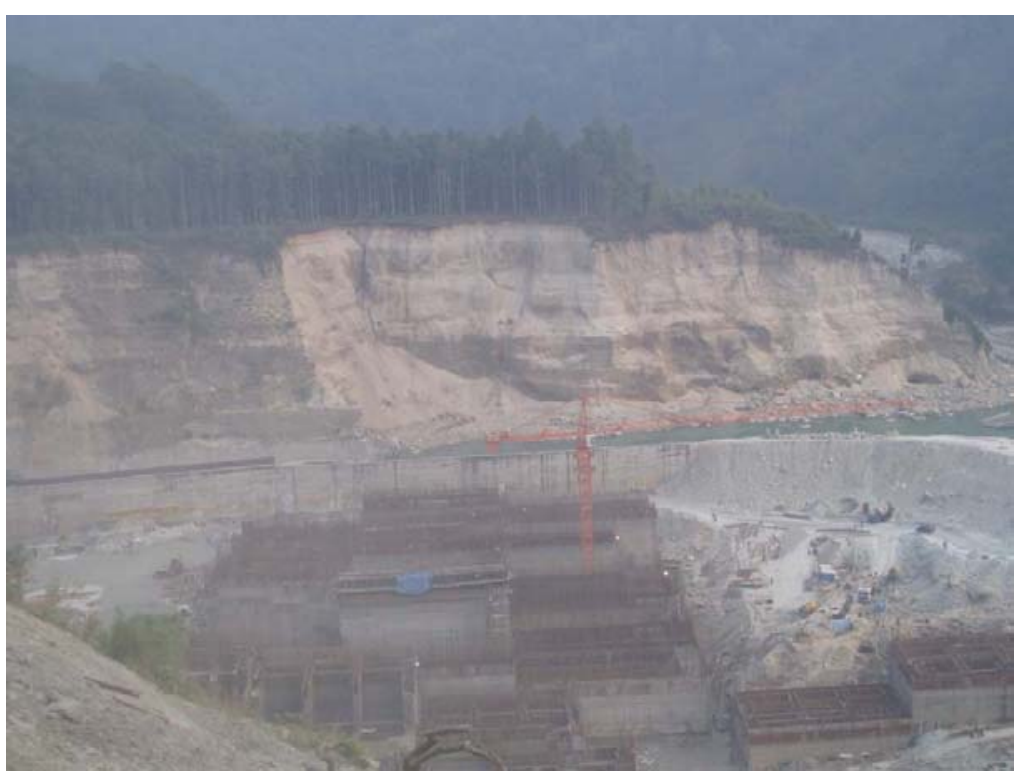

Photo 5: Hydel on Teesta on Sikkim-West Bengal border

The Lepchas who are fighting the construction of hydels in the Dzongu take heart from a battle fought ten years earlier in West Sikkim by a group called Concerned Citizens of Sikkim. It was this fight over the sacred landscape at Yoksom in West Sikkim, (which was also identified as being a biodiversity hotspot by the WWF in 1992-93) that brought the Lepchas and Bhutias together as activists to fight the building of the Rathong Chu hydro electric project in the early 90s. The outcome of a defiled landscape was the chief argument used by the activists protesting against the implementation of the Rathong Chu hydroelectric project. They argued that the project infringed their indigenous rights in land and violated Article 371f of the Indian Constitution. The battle was fought partly in the monasteries around Sikkim with lamas conducting major

\footnotetext{
${ }^{42}$ Sarikah Atreya Show of Strength, Dzongu Divided over Panam, Midweek, 20-26 September, 2006, Gangtok, p. 1, 5

${ }^{43}$ Ibid p.1
} 
pujas to stop the project and led to Lama Sonam P Denzongpa, a founding member of Concerned Citizens of Sikkim, undertaking a 28 day hunger strike. ${ }^{44}$ The publication Hill People, reported that 'the main grouse of the anti-project activists seems to be that if the project is implemented in toto it would go against the "natural and cultural heritage” of the Sikkimese people. While the Government has threatened anyone who tries to oppose the project on the grounds of religion, culture and environment, the CCS has maintained that at the cost of religion, culture and environment the Government cannot go ahead with its 'developmental' programmes. ${ }^{45}$

Choudhury, in his report on the Teesta Hydel Scheme referred to the environmental battle: 'In recent past, Sikkim witnessed another potential conflict situation between ethnic Bhutias and the state administration run by the majority Nepalese over the issue of Rathong $\mathrm{Chu}^{46}$ Hydro-electric Project in West Sikkim. The ethnic Bhutias, especially the Buddhist lamas were up against the state administration over the construction of a power project in close proximity of sacred heritage sites. For quite some time there was an impasse over the construction of the power plant. Before the conflict took destructive proportions, the state administration scrapped the power project. ${ }^{97}$

This region has a number of glacial lakes in the higher reaches. These are considered holy lakes by the Sikkimese. The Rathong Chu is said to have its source in nine holy lakes at the higher elevations, close to the mountain peaks. The river in the Yoksum region itself is considered to have 109 hidden lakes. These visible and less obvious notional lakes identified by religious visionaries are said to have presiding deities, representing both good and evil. Propitiating these deities through various religious ceremonies is considered important for the welfare of the Sikkimese people.

The Bum Chu ritual, considered holiest of all festivals, is held annually at Tashiding. The Rathong Chu is said to turn white and start singing, and this is the water to be collected at the point where the Rathong Chu meets the Ringnya Chu. Attracting

\footnotetext{
${ }^{44}$ Interview with Pema Namgyal, one of the founders of CSS, 3 January 2007.

${ }^{45}$ Pema Wangchuk, (1995) Hunger strike against Rathong Chu Project Hill People July 1995, p.3

${ }^{46}$ Chu means river

${ }^{47}$ Maitreyee Choudhury, (nd) Carrying Capacity Study of Teesta Basin in Sikkim Volume-X, Sociocultural, Environment, Chapter 4, p. 85-86. Commissioned by Ministry of Environment and Forests, Government of India, Sponsored by National Hydroelectric Power Corporation Ltd., Fairdabad.
} 
thousands of devotees from the state and the neighbouring region, the Bum Chu ritual is predictive in nature, in that it is suggested to be indicative of coming events - possible calamities or prosperity for the people of Sikkim. The water kept in vases, if it overflows, is indicative of prosperity. Decline in water level is indicative of bad events such as drought, disease, etc. Turbid water is indicative of unrest and conflicts.

The Government of Sikkim had requested PS Ramakrishnan's independent assessment of the sacredness of the landscape surrounding Rathong Chu that the Concerned Citizens of Sikkim (CSS) claimed was sacred land. Ultimately, Ramakrishnan, after consulting with the Buddhist community in Sikkim, agreed with the CSS and advised against the project proceeding. He later wrote: 'The Sikkimese sacred landscape...is a unique case where ecological considerations cannot be separated from historical, social, cultural and religious dimensions. Here is a sacred landscape where the people are truly integrated within the landscape unit itself, in a socio-economic sense. ${ }^{49}$

The state government was forced to rework its attitude towards the environment by according legitimacy to the 'indigenous' relationship with the landscape and affirm its commitment towards preserving their cultural heritage embodied in their sacred sites. In November 1998, the Home Department of the Government of Sikkim issued a notification 'prohibiting the conversation of any place of worship and instructing the administration to maintain their status quo. Hence, the State government declared: 'no conversion or alteration of new construction or any developmental activity shall be undertaken at the site or in the close vicinity of any place of worship or religious institution of sacred lakes or of sacred peaks.' A list of sacred peaks, sacred caves, sacred rocks, sacred lakes, stupa and hot springs was included in this notification to prevent the occurrence of ethic conflict in Sikkim. ${ }^{50}$

\footnotetext{
${ }^{49}$ P S Ramakrishnan, (1998) Ecology and Traditional Wisdom, The Cultural Dimension of Ecology, Pub. Indira Gandhi National Centre for the Arts (IGNCA) and D K Printworld Pvt Ltd New Delhi. P.7

50 Arora Vibha, The Forest of Symbols Embodied in the Tholung Sacred Landscape of North Sikkim, India, pp. 73-74
} 
After their success in stopping the damming of the Rathong-Chu, the CSS persuaded the government to stop issuing permits for mountaineering teams to climb Mount Kanchenjunga. An Austrian team had come to Sikkim in April 2000 and paid the Sikkim Home Department US\$20,000 for a climbing permit for Mount Kanchenjunga. When the CSS learned this they wrote to sponsors of the expedition asking that they withdraw their support for the climb. 'Perhaps you did not know that Kanchenjunga is our National religious treasure the place where our protecting deities reside. To us, the mountain itself is a shrine and just as you would not climb on a statue of Jesus or Buddha or leave oxygen canisters or trash in its lap we do not believe in trampling on Kanchenjunga...it seems our state government has disregarded the sentiments of our people and sold the purity of our religious treasure for $\$ 20,000 \ldots$ there are many mountains to climb that are not sacred, but our Kanchenjunga is not one of them., ${ }^{51}$

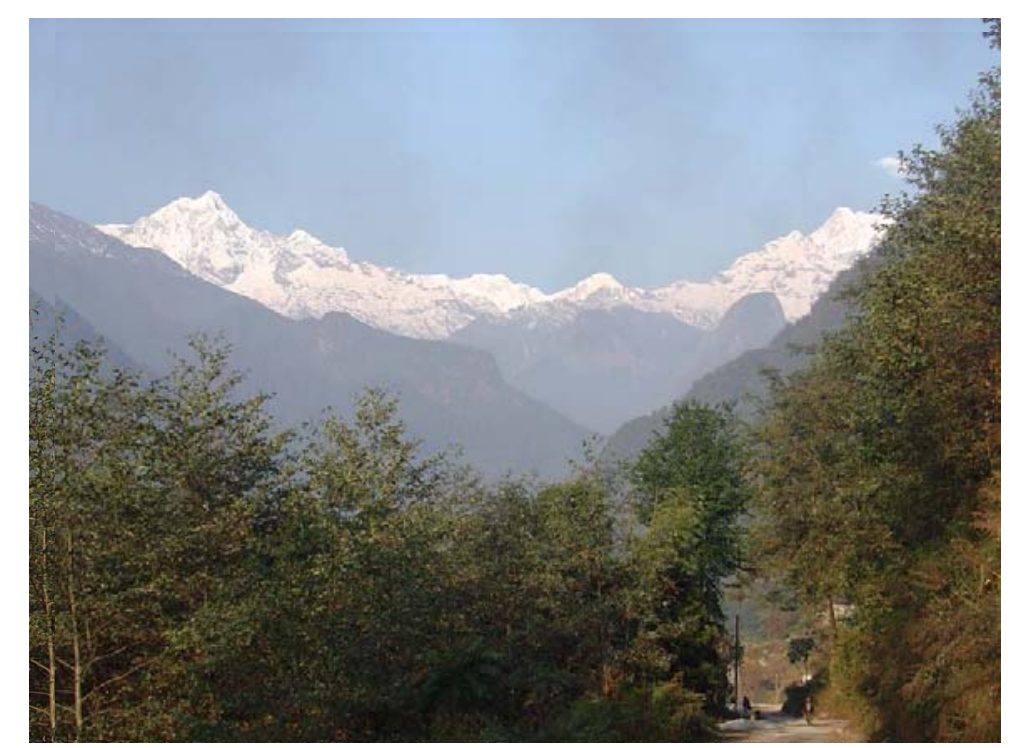

Photo 6: Kanchenjunga range seen from Dzongu Lepcha Reserve

The Austrian mountaineers were not allowed to unfurl their flag atop Kanchenjunga and agreed a compromise with the Government of Sikkim. 'They will do the symbolic honours 10 metres short of the 8,586 metres peak because of restrictions by the Sikkim government to maintain its "sacred" status. ${ }^{52}$ This compromise was not acceptable to the CSS and they continued their campaign to stop the expedition from starting. Even though they were unsuccessful, when the climbers reached advanced base camp, they were unable to proceed due to bad weather. "We had never seen anything like it in

\footnotetext{
${ }^{51}$ Email send 18 April 2000 to funworld (expedition sponsor) by Concerned Citizens of Sikkim $52<$ http://www.the-south-asian.com/Sept2000/Unconquered\%2020\%20peaks.htm>, accessed 6 March 2006
} 
Sikkim,” Pema Namgyal from CSS recalls. “At 1.30 in the afternoon we had to turn on the lights. It was pitch black outside and people had to drive with their car lights on. The weather was so bad that they couldn't climb our mountain.” I ask him if they had done pujas asking for bad weather but he rejects this. "We did pujas asking our mountain deity to forgive the climbers for intruding on her. We were warning her that they were coming to walk all over her." 53

The climbers tried to get a helicopter to take them above the storm further up the mountain but it was unable to land. They had to abandon their climb and soon after, the government placed a ban on expeditions to Mount Kanchenjunga and seven other sacred peaks. 'It is a gesture of respect for the religious sensitivities of the people who regard the mountain as a deity,' Sikkim's former chief minister, BB Goorong, said. ${ }^{54}$

Between Gangtok and the Dzongu there is a sacred grove called Kabi Longstock, where in the $14^{\text {th }}$ century, a treaty of friendship was signed in blood between the Lepcha and Bhutia chiefs. Nine 'divine' upright stones were erected to mark the place and hold their sacred covenant -Laong Tsaok, meaning the erected standing stone. ${ }^{55}$ The entry in the website of the Department of Information and Public Relations of the Government of Sikkim describes the event: 'A great and deep friendship grew between the Lepchas and the newcomers. Khey Bumsa and the Lepcha chief Thekong Thek swore blood brotherhood and signed the same in blood at Kabi Longstock. To this day the pact is celebrated in Sikkim. The story symbolically rationalises the alliance between the traditional Lepcha-Bhutia ruling elite in Sikkim. ${ }^{, 56}$

Arthur Foning Lepcha, author of Lepcha, My Vanishing Tribe saw the signing of this treaty at Kabi Longstock as a symbol of betrayal. 'It was here that the ancestors of the rulers of Sikkim hailing from a foreign country vowed eternal friendship and fraternity with the Lepchas and, ultimately, on the strength of this covenant, enacted by raising these upright stones with full religious ceremony, they ascended the throne as Chogyals,

\footnotetext{
${ }^{53}$ Pema Namgyal related to this story in Gantok in January 2007

${ }^{54}$ Harding Luke, Climbers Banned from North East Face of Kanchenjunga, The Guardian, July 13, 2000 (accessed 5/2/08).

$55<$ http://sikkim.nic.in/north/html/lepcha.htm>

$56<$ http://www.sikkiminfo.net/modern_history.htm>
} 
or Dharma Rajas, the priest kings. The simple and guileless Lepchas, in obedience to the divinity attached to these upright stones, without so much as a yeah or ney, acknowledged these intelligent and clever people as their own divine kings. ${ }^{, 57}$

The Lepcha social activists who form the Affected Citizens of Teesta and oppose the hydels aren't simple and guileless. They are well educated and many have studied or worked outside of the Sikkim. In fact these modern day Lepchas defy the descriptions written by the early British political officers and adventurers who encountered Lepchas in the late 1800s and early 1900s and described them variously as '...peaceful and gentle character[s]... evinced by their numerous terms of tenderness and compassion...the trees and the flowers, and the birds, and the insects have heretofore been their friends and companions ${ }^{, 58}$; 'being people of a mild, quiet and indolent disposition,59; 'timid, peaceful and no brawler' and 'amiable and obliging, frank, humorous, and polite. ${ }^{, 60}$

However, the activists point out that it is the Lepcha's lack of sophistication that has made them vulnerable to the government and hydro companies. 'Many poor farmers get ruined due to [their] inability to utilize the compensation money and suffer hardships later because their only source of livelihood has been taken away. ${ }^{61}$ A CLOS press release in support of the meeting at BL House on 12 December 2007 states that 'hydel projects in the Dzongu will bring adverse effects on the Lepcha inhabitants and that...it is also a fact that considering that the simple and god fearing Lepchas can easily be carried away by the material temptations, the vested interests may use ulterior motives to achieve this at the cost of the poor and innocent Lepchas'. ${ }^{62}$

The public face of the activists has been dominated by the Lepcha youth - the boys in jeans - who were prominent and vocal at the BL House meeting, however these young, modern activists are aware of the importance of ensuring that their elders are fully

\footnotetext{
57 Arthur Foning, Lepcha, My Vanishing Tribe, Kalimpong, Chyu-Pandi Farm, 2003 (first published 1987) p. 37

${ }^{58}$ Mainwaring; cited in Morris 1938 p.37-38

${ }^{59}$ White 2000 p.7-8.

${ }^{60}$ Hooker 1999 p.129

${ }^{61}$ ACT responds to hydel supporters, questions and raises concerns, NOW! 10 July 2007, p.1,

${ }^{62}$ Concerned Lepcha of Sikkim backs ACT, Sikkim Express, 12 December 2006, p.1
} 
appraised of the reasons for their protest, for it is the elders and the lamas who hold significant influence over opinion in the Dzongu.

Vibha Arora notes that the idea of a sacred grove often mistakenly implies the exclusion of people from the landscape but there cannot be a sacred grove of a forest without the forest-dweller and his beliefs and practices. The sacred groves are extremely humanised landscapes. The rituals performed by the Lepchas regenerate the human body, the land, the ancestral connections of the Lepchas and their indigenous identity and that sacred landscapes such as Kabi and Tholung sacred groves embody Lepcha culture and indigenous knowledge systems. ${ }^{63}$ She quotes Athup Lepcha, the Lepcha ideologue (and president of the ACT) who she met in Lingthem village in the Dzongu: 'to be Lepcha means to belong to a place. The word Lepcha originates from the union of two Lepcha words Lep and Tsa which means to belong to a place., 64

This belonging to place explains Tseten Lepcha of the Affected Citizens of Teesta's description of the impact of the multiple power projects: 'The history, the ethos, the folklore of Sikkim is connected with the Teesta and it is practically going to vanish. ${ }^{65}$ His words are reinforced by his activist colleague Dawa Lepcha who, with other members of the Lepcha community, wrote to the Government of Sikkim seeking the review of stage III and IV of the Teesta Hydro project saying: 'the land which we have under our possession is our ancestral land tied to our culture and history and dear to us. Our religion based on nature will be destroyed by the advent of such a large project. Our delicate social, cultural and historical fabric will be destroyed by the advent of such a project. The delicate ecosystem of the valley will also be destroyed. The coming of large numbers of workers for the project will unbalance the demographics of the area having long term repercussions on the survival of our tribe. ${ }^{66}$

\footnotetext{
${ }^{63}$ Arora 2006 p.61

64 There are various meanings of the word Lepcha, documented. Athup Lepcha's meaning is not widely quoted.

65 Simon Denyer, Indian Plan to Dam Northeast Rivers Stirs Critics, Planet Ark World Environment News, www.planetark.com 21 June 2006 (accessed 31/10/06).

${ }^{66}$ Quoted in Environmental and Social Impacts of Teesta Hydroelectric Project, Sikkim, An Investigation Report, found on http://www.esgindia.org/moefsuno2005/Teesta\%205\%20Dam\%20Sikkim.doc. Quote confirmed to be correct by Dawa Lepcha in March 2007.
} 
Gyatso Lepcha, President of CLOS adds: 'the issue is not just about whether we are giving our land for the project or not. It has much larger implications. It is the question about our very survival. If we have our land we can flourish as a race, as a community. Our ancient practices, our cultural heritage can be preserved for future generations. With our land gone, we will be finished as well. We will die but we will not give our land. ${ }^{67}$

A young man stands outside BL House. He wears baggy blue pants, and a collared shirt - but over the top he has slung a Thokro-Dum. At another time this combination may appear incongruous, but this is the day when Lepchas of all ages, education and jurisdiction have come together in one place to learn of the threat to their holy land and agreed to fight it together. In this environment, he looks like a young man who easily traverses his modern life with the traditional world of his elders. He is gazing over his shoulder, as though expecting something to happen. Perhaps he is waiting for a revolution.

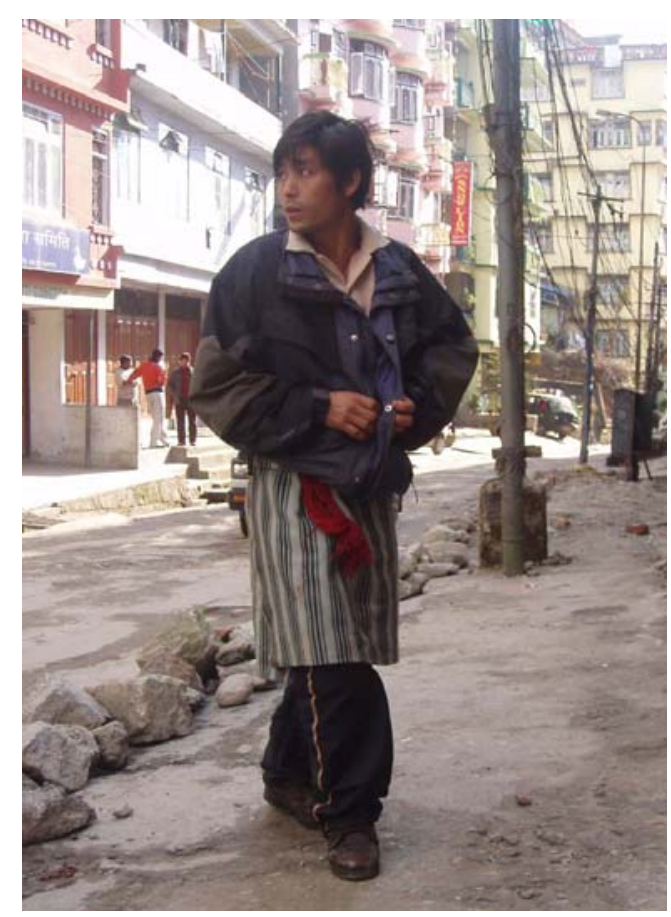

Photo 7 - Young man outside BL House wearing Thokro-Dum

${ }^{67}$ Mita Zulca (2007) Protest in the Hills, Talk Himalaya July-Aug 2007. 
I returned to Sikkim a year after the 12 December 2006 meeting to find a revolution of sorts unfolding at Bhutia Lepcha (BL) House. On the $20^{\text {th }}$ June 2007, Dawa Lepcha from ACT and Tenzing Lepcha from CLOS led a hunger strike at BL House in Gangtok to protest the Government's policy on the Dzongu hydro electric projects. They fasted for 63 days and in that time captured the attention of the people of Sikkim and support from Lepchas and others living outside the state and outside India. They stopped only when the Chief Minister of Sikkim again promised to conduct a review into the projects. The terms of reference for the review were later rejected by the ACT and CLOS as the wording stated that it was a 'review committee for the implementation of the projects.'

When I return in December 07 the Lepchas are conducting a relay hunger strike outside BL House and around 15-20 young Lepchas, including Dawa and Tenzing, have moved into the building which has become a headquarters of sorts for ACT. There, in the draught and dust and crumbling concrete, for the building was never completed, they prepare to commemorate 200 days since the beginning of the hunger strike. Lepchas from Kalimpong and Darjeeling who have vigorously supported the movement are preparing to join them. I am unable to visit Dzongu until the 200 days event is finished for the young Lepchas who would usually act as my guides and interpreters are all members of ACT or CLOS and are either on hunger strike or making preparations for the meeting. I spend the time at BL House, asking them about the impact of the movement on their lives and each of them says that because of the movement they want to learn about their culture; they want to learn the stories, the way their elders use nature as medicine and the Lepcha names for plants, birds and trees. One of the activists, 23 year old Tenzing Lepcha (who was on hunger strike for 63 days), tells me 'We have gained knowledge of our culture and it is important because right now, as far as I know, most of the youth of our age don't concentrate on their culture at all. It's a very important thing which we should keep in mind and we should preserve. If we know it [culture] then we can pass on these things to coming generations.'

“Before this movement I grew up here and I studied here [Gangtok] but I didn't get a chance to study my language. I know how to speak but I don't know how to write because there were no Lepcha language classes in our school (Tashi Namgyal Academy), so right now I am learning and I want to learn as much as I can so that tomorrow I can tell my brothers and sisters, even our children in coming days, how to 
preserve culture, tradition and how valuable our script is because if we don't look after these things today then tomorrow they will vanish.”

Tenzing's comments were echoed by his fellow activists. Twenty-six year old Ongel Lepcha has written a song about the movement and about his love for Dzongu. He sings it for me and then roughly translates it. "We have the feeling of Dzongu, but we are afraid our land will go in the hands of capitalists. For this we are fighting without food. With the help of the morning tomorrow, perhaps our dream will be a reality. For this we are fighting, drying our blood while we stay on strike. River Teesta is looking for help, it is vanishing in the tunnels but nobody is listening to my voice."

Later I visit Tenzing's village, Hee Gyatang in Lower Dzongu and he takes me to meet his father Nethuk, who tells me the story of the creation of their clan, Affimoo. We also meet another elder relative, Choden who has great knowledge about Lepcha stories and medicine and tells us a story about Nethuk that Tenzing had never heard - that his father was abducted by an evil spirit when he was two years old and found days later after a Mun (priestess) had gone into a trance and 'seen' his whereabouts. The next morning, when Nethuk comes, Tenzing asks him to retell the story. 'I want to know everything,' he says. 'I want to learn and record everything there is to know about my people.'

I travel to Tingvong village in Upper Dzongu with another activist, Pema Lepcha who has left his job in Kolkata where he worked as a lawyer to work for ACT. We meet a hunter and a story-teller and record their stories about hunting and wedding rituals. Pema, like Tenzing is also hearing the stories for the first time and we joke that by working together we are conducting 'non-traditional passing down of stories.'

These Lepcha youth are the men in jeans who I first met at the rally a year earlier. The first educated generation who, faced with the prospect of losing their land, are determined to keep not just their land but the traditions that go with it. They have always thought of Dzongu as their holy place but now they are excavating their narratives to learn why it is sacred. They have always described themselves as natureworshippers but they are now learning the traditions behind living as natureworshippers. 
The activists have plans for their Dzongu, once their battle with the government and the developers has been won. They tell me they will return there and start new businesses in organic farming and eco-tourism; and that they will build good schools so that the next generation will be well educated without having to leave the Dzongu. When I meet Dawa Lepcha's young children I ask him if he will pass on his story to them; that he and Tenzing starved themselves for 63 days to save their land and he smiles and says 'maybe'. We walk up the steep steps through his village, Lingdong and he tells me how his involvement in the movement started. "I was walking up here, looking at these mountains, the trees, the land - our land - and I thought; they can't take this. They can't do this thing to our land.”

Dawa's decision to act against the dams has had an unplanned consequence of bringing young Dzongu Lepchas back to their traditions. Their love for their holy Dzongu is now openly expressed; in stories, in songs and in the protest banners that adorn the walls of BL House. If the movement is successful it will do more than stop the destruction of nature - it may well save a culture that was threatened by the lack of a clear and present danger for the youth were gradually drifting away, influenced by the culture shown on cable television and other more dominant cultures outside Dzongu. The telling of traditional narratives - whether in traditional or 'non-traditional' ways to and by Lepcha youth is happening as a result of this movement. My role as a recorder of these narratives is informed and enhanced by this contemporary story that is currently the context for my research. The young, English speaking Lepcha are, while translating, adding their own narrative to their traditional stories, greatly enriching my understanding of how the stories have currency now.

Near the end of my most recent trip to Lepcha Land I ask a young Lepcha from Kalimpong who has visited but never lived in Dzongu what it means to him. He says: “The Dzongu is our heartbeat. They have sliced away every other part of us but our heart remains. This small heart is what keeps us alive." 


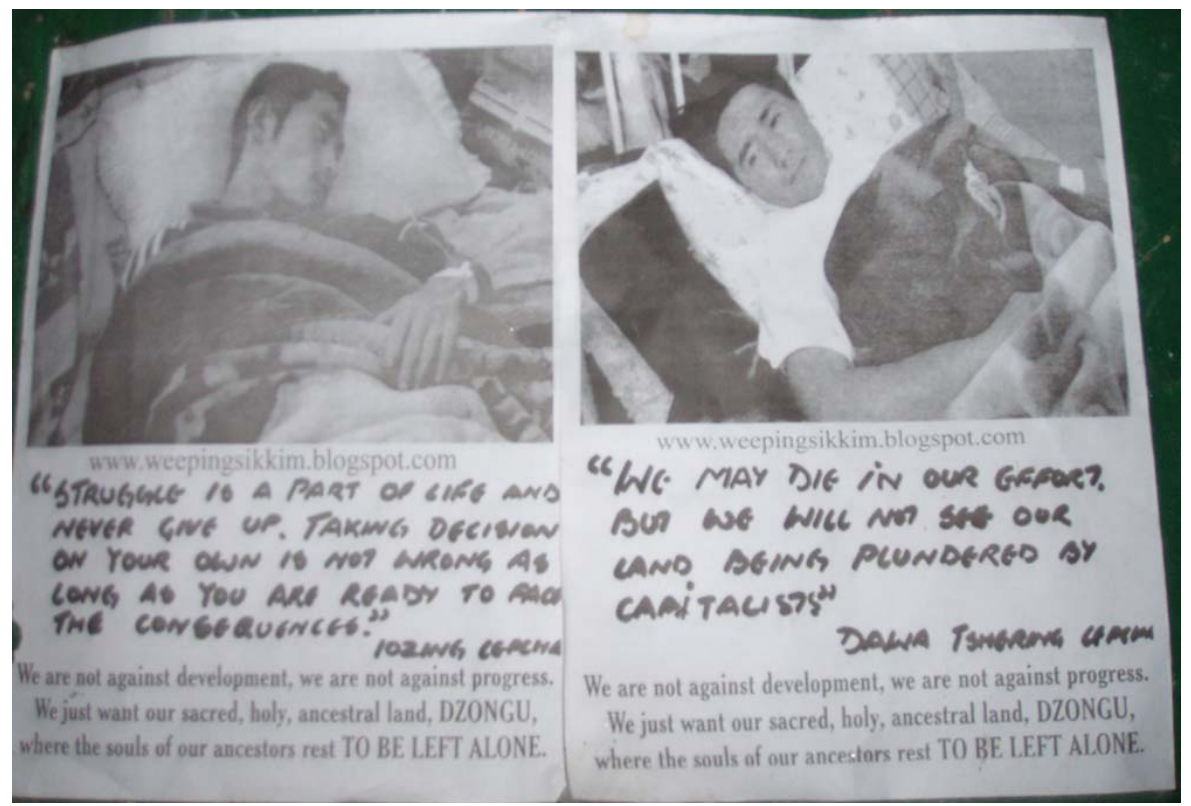

Photo 8: Poster of Tenzing and Dawa on hunger strike posted to the wall of a house in Dzongu.

\section{Bibliography}

Arora, V (2006) The Forest of Symbols Embodied in the Tholung Sacred Landscape of North Sikkim, India, Conservation and Society.

Atreya, S (2006) ACT supporters detained for questioning, Midweek, Gangtok.

Atreya, S (2006) Show of Strength, Dzongu Divided over Panam, Midweek, Gangtok.

Chamling, P (2001) Politics, Programmes and Vision for the new Century, New Year speech, Gangtok.

Choudhury, M (nd) Carrying Capacity Study of Teesta Basin in Sikkim Volume-X, Socio-cultural, Environment, Ministry of Environment \& Forests, Government of India, Delhi.

Dharmadhikary, S (2007) Have river, will dam, HIMAL SOUTHASIAN, September.

Dutta, S (2007) Lepcha v hydropower, HIMAL SOUTHASIAN, September.

Foning, A (2003) Lepcha, My Vanishing Tribe, Kalimpong, Chyu-Pandi Farm.

Harding L (2000) Climbers Banned from North East Face of Kanchenjunga, The Guardian, London.

Hooker, J D (1999) Himalayan Journals, Natraj Publishers, Dehru Dun (first published 1854).

King Gaeboo Achyok Birth Anniversary (2006) A Lepcha Bilingual Magazine, Indigenous Lepcha Tribal Association, Kalimpong.

Mitra, M (2007) Sikkim's tribesfolk protest against damming river Teesta, Down to Earth, New Delhi.

Morris, J (1938) Living with the Lepchas, William Heinemann Ltd, London.

Rai, R (2006) CM offers to review 'every aspect' of North Sikkim, NOW! Daily, Gangtok. 
Ramakrishnan, P S (1998) Ecology and Traditional Wisdom, The Cultural Dimension of Ecology, Indira Gandhi National Centre for the Arts (IGNCA) and D. K. Printworld Pvt. Ltd, New Delhi.

SE News Bureau (2006) Concerned Lepchas of Sikkim backs ACT, Sikkim Express.

The Land Use and Environment Circle, Forest, Environment and Wildlife Management Department (2005) Report on World Environment Day, 2005, Government of Sikkim, Gangtok.

Wangchuk P (1995) Hunger strike against Rathong Chu Project, Hill People, Gangtok.

White, J.C. (2000) Twenty-one Years on the North-East Frontier 1887-1908, Asian Educational Services, New Delhi 2000.

Zulca, M (2007) Protest in the Hills, Talk Himalaya, Little Kingdom, Gangtok.

\section{Online media sites and other online source material*}

Tehelka

http://www.tehelka.com/story_main34.asp?filename=cr290907SATYAGRAHA.asp

The Hindu

<http://www.thehindu.com/thehindu/mag/2004/06/06/stories/2004060600260400.htm>

The Statesman

$<$ http://www.thestatesman.net/page.arcview.php?date=2006-01-

26\&usrsess $=1 \&$ clid $=10 \& i d=132102>$

Sikkim government information site

$<$ http://www.sikkiminfo.net/modern_history.htm>

$<$ http://sikkim.nic.in/north/html/lepcha.htm>

$<$ http://www.sikkimipr.org/GENERAL/ECONOMY/ECONOMY.HTM>

Planet Ark

<http://www.planetark.com/avantgo/dailynewsstory.cfm?newsid=36919>

The South Asian.com

<http://www.the-south-asian.com/Sept2000/Unconquered\%2020\%20peaks.htm>

(* accessed between October 2006 and September 2007.) 